TABLE 1

\begin{tabular}{|c|c|c|c|c|}
\hline & \multirow{2}{*}{$\begin{array}{c}\text { Before } \\
\text { transfusion }\end{array}$} & \multicolumn{3}{|c|}{ After transfusion } \\
\hline & & $24 \mathrm{hr}$ & $72 \mathrm{hr}$ & 6 days \\
\hline Haemoglobin $(\mathrm{g})$ & ND & $7 \cdot 5$ & $7 \cdot 6$ & $7 \cdot 6$ \\
\hline PCV & 20 & 29 & 23 & 29 \\
\hline Plasma free $\mathrm{Hb}(\mathrm{mg} / 100 \mathrm{ml})$ & 241 & 141 & 5 & 6 \\
\hline Bleeding time & 14 & 6 & 4 & 1 \\
\hline Clotting time & No clot & 8 & $5 \cdot 5$ & 2 \\
\hline Haemolysins & $3+$ & \pm & - & - \\
\hline Serum bilirubin $(\mathrm{mg} / 100 \mathrm{ml})$ & $4 \cdot 0$ & 4.8 & $1 \cdot 3$ & 0.6 \\
\hline Urine volume $/ 24 \mathrm{hr}(\mathrm{ml})$ & 970 & 1750 & 1500 & 1300 \\
\hline Haemoglobinuria & $4+$ & $1+$ & - & - \\
\hline Urobilin & $2+$ & $3+$ & $3+$ & $1+$ \\
\hline Blood urea $(\mathrm{mg} / 100 \mathrm{ml})$ & 30 & 148 & 75 & 32 \\
\hline Serum $\mathrm{Na}(\mathrm{mEq} / \mathrm{l})$ & & & 136 & 140 \\
\hline Serum K $(\mathrm{mEq} / \mathrm{l})$ & 3.8 & $4 \cdot 2$ & $4 \cdot 6$ & $4 \cdot 6$ \\
\hline Serum $\mathrm{HCO}_{3}(\mathrm{mEq} / \mathrm{l})$ & $21 \cdot 2$ & $27 \cdot \overline{6}$ & $28 \cdot 4$ & $30 \cdot 0$ \\
\hline SGOT Frankel Units & ND & 110 & 84 & 36 \\
\hline SGPT Frankel Units & & 94 & 96 & 68 \\
\hline
\end{tabular}

\section{Acknowledgment}

We are greatly indebted to Dr P. E. Gunawardena, Superintendent of the National Blood Transfusion Service for his help in this case.

\section{Reference}

ReID, H.A. (1968) Snake bite in the tropics. Brit. med. J. 3, 359.

\title{
Congenital Heinz-body haemolytic anaemia due to Haemoglobin Hammersmith
}

\author{
N. K. SHINTON \\ M.D., M.R.C.P., M.C.Path.
}

\author{
D. C. Thursby-Pelham \\ M.D., M.R.C.P., D.C.H.
}

\section{H. PARRY Williams \\ M.R.C.S., F.R.C.P.}

\section{Coventry and Warwickshire Hospital and City General Hospital, Stoke-on-Trent}

THE ASSOCIATION of haemolytic anaemia with red cell inclusion bodies was well recognized at the end of the Nineteenth Century in workers exposed to coal tar derivatives (Heinz, 1890a, b) and following potassium chlorate poisoning (Reiss, 1882). Since then a variety of drugs and chemicals have been shown to induce the formation of these so called Heinz bodies in large numbers (Dacie, 1967). Small numbers are seen after splenectomy for any cause (Webster, 1949). A child was described by Cathie (1952) who had undergone splenectomy for a congenital haemolytic anaemia and who had a persistently high frequency of red cell Heinz bodies and who had not been exposed to a toxic agent likely to be responsible for the phenomena. A similar case reported by Lange \& Ackeroyd (1958) was later

* Requests for reprints should be sent to Dr N. K. Shinton. shown by Zinkham \& Lenhard (1959) to be associated with an hereditary deficiency of the red cell enzyme glucose-6-phosphate dehydrogenase. Anomalies in haemoglobin electrophoresis were noted in cases of congenital Heinz body haemolytic anaemia by Schmid, Brecher \& Clemens (1959) and by Scott et al. (1960) without the nature being identified. The association with an identifiable haemoglobin anomaly-Haemoglobin Zurich, was reported by Frick, Hitzig \& Betke (1962). Haemolytic episodes here followed the ingestion of sulphonamides. Spontaneous haemolysis with Heinz body formation was later described in association with other abnormal haemoglobins-Haemoglobin Köln (Pribilla, 1962), Haemoglobin Ube-I (Shibata et al., 1963), Haemoglobin Gallier Genova (Sansome \& Pic, 1965), Haemoglobin Seattle (Huehns, 1965) and 
Haemoglobin St Mary's (Huehns, 1965). A further anomaly of haemoglobin structure-Haemoglobin Hammersmith-was recently described (Dacie $e t$ al., 1967). This was based on two unrelated patients, the clinical details of one having been previously reported by Grimes, Meisler \& Dacie (1964). The second case is here described.

\section{Case report}

The patient (L.W.) was a female born in June 1963 following a normal gestation and delivery. Jaundice was present at birth, the cord blood serum bilirubin being $7.6 \mathrm{mg} / 100 \mathrm{ml}$, haemoglobin $13.6 \mathrm{~g} / 100 \mathrm{ml}$, direct Coombs' test negative. The jaundice cleared after 2 weeks and development was normal until 10 months of age when she was admitted to hospital with gastroenteritis. She was then noticed to be pale and slightly jaundiced with a palpable spleen. Haemoglobin was $6 \cdot 2 \mathrm{~g} / 100 \mathrm{ml}$ with $46 \%$ of red cells being reticulocytes; Romanowsky stained red cells showed hypochromia, much polychromasia, occasional punctate basophilia, spherocytes and orthochromic normoblasts in moderate numbers. No Heinz bodies or intracellular inclusions were seen in vital stained films. The red cell osmotic fragility was increased, lysis beginning in $0.75 \% \mathrm{NaCl}$ solution and being incomplete in $\mathbf{0 . 2} \%$ solution with an $\mathrm{MCF}$ of $0.47 \% \mathrm{NaCl}$. After incubation at $37^{\circ} \mathrm{C}$ for $24 \mathrm{hr}$, $5 \%$ lysis occurred in $0.9 \% \mathrm{NaCl}$. Tests for sickling were negative. Direct and indirect anti-human globulin tests were negative. The serum bilirubin at this time was $2.5 \mathrm{~g} / 100 \mathrm{ml}$ (unconjugated) and haptoglobin $20 \mathrm{mg} / 100 \mathrm{ml}$. The child was transfused with $200 \mathrm{ml}$ of concentrated red cells which raised the haemoglobin to $13.3 \mathrm{~g} / 100 \mathrm{ml}$, but it had returned to a level of $9 \cdot 1 \mathrm{~g} / 100 \mathrm{ml} 6$ weeks later.

During the next 12 months the haemolytic anaemia persisted and required a transfusion every 6-8 weeks to maintain the level of haemoglobin between 7 and $9 \mathrm{~g} / 100 \mathrm{ml}$. Examination of red cell enzymes in July 1965 showed a level of glucose-6phosphate dehydrogenase 227 units (normal range 120-180 units), pyruvate kinase 480 units (normal range 120-180 units) and glutathione reductase 110 units (normal range 100-200 units). Haemolysate contained $17 \%$ haemoglobin $\mathrm{F}$; paper electrophoresis at $\mathrm{pH} 7.5$ showed haemoglobin A only.

In August 1965 the red cell survival time was estimated using the patient's own cells tagged with ${ }^{51} \mathrm{Cr}$; the half-time was only 2 days. Body scanning showed considerable radioactivity over the spleen which reached a peak at 2 days falling steadily over the next 12 days. This was regarded as justifying splenectomy which was carried out in October 1965. The spleen and an accessory spleen weighed together $110 \mathrm{~g}$ and showed small Malpighian bodies in which germinal centres were clearly visible. There were moderate numbers of red cells in the splenic pulp $\bar{\alpha}$ together with large deposits of iron pigment, some of $\propto$ which was intra-cellular and some lying free in the $c$. splenic pulp. Following the operation, haemolytic $\overrightarrow{\vec{F}}$ anaemia persisted with a haemoglobin level between $\overrightarrow{0}$ 7 and $9 \mathrm{~g} / 100 \mathrm{ml} ; 30-70 \%$ of red cells being reticu- $\frac{\mathrm{C}}{0}$ locytes. The Romanowsky stained cells showed gross $\overline{\bar{c}}$. distortion with basophilic stippling (Fig. 1). Cells $\widehat{\widehat{\Phi}}$ stained with brilliant cresyl blue showed $36 \%$ con- $\frac{\circ}{\circ}$ taining inclusion bodies (Fig. 2). Osmotic red-cell- $ळ$ fragility tests showed no change from previous $\overrightarrow{0}$

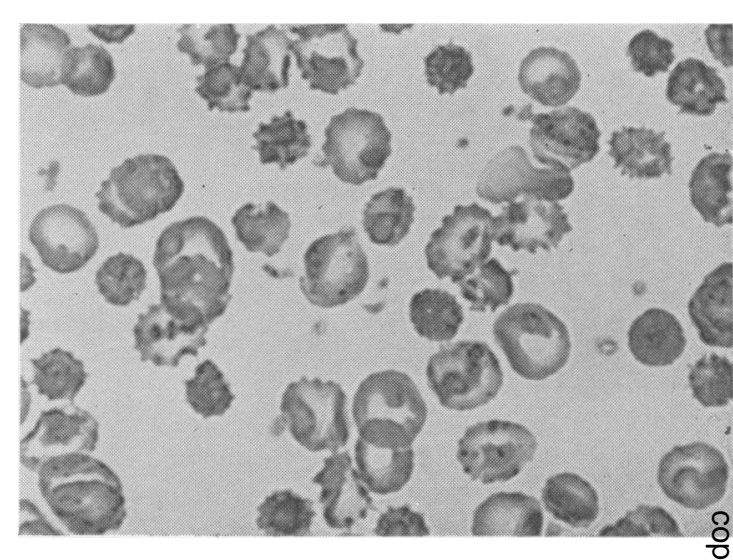

FIG. 1. Photomicrograph of Romanowsky stained blood film following splenectomy. There is gross distortion of red cells and basophilic stippling. $\times 960$.

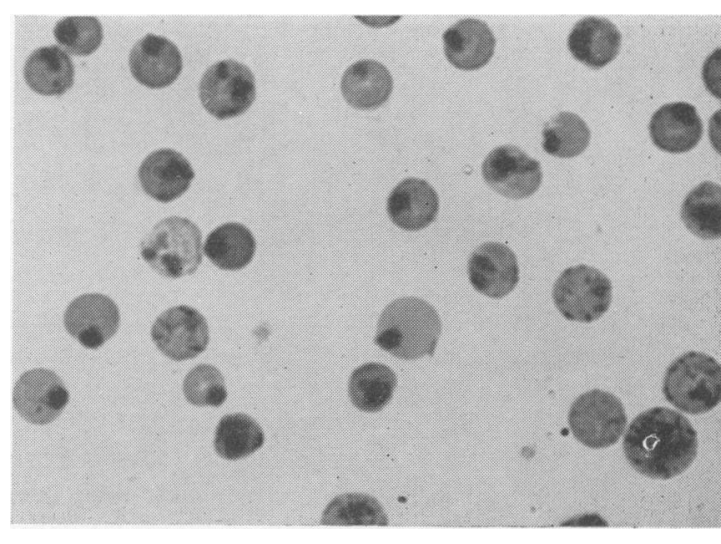

FIG. 2. Photomicrograph of Brilliant cresyl blue stained blood film following splenectomy. There are numerous coarse inclusion bodies in the red cells. $\times 960$.

observations. There was no methaemoglobin present in fresh or incubated blood but a precipitate was

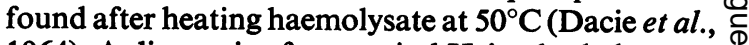

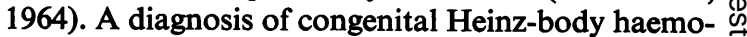
lytic anaemia was made and specimens submitted 0 to the M.R.C. Abnormal Haemoglobin Unit for 
further evidence of an unstable haemoglobin. Professor Lehman reported that there were no peptide chains carrying charges different from those of normal $\alpha$ - and $\beta$-chains of haemoglobin $A\left(\alpha_{2} \beta_{2}\right)$ when the haemoglobin was submitted to starch gel electrophoresis in $6 \mathrm{~m}$-urea. On finger-printing and peptide residue analysis the changes were those of an abnormal haemoglobin similar to that found in the case reported by Grimes et al. (1964) which was subsequently termed Haemoglobin Hammersmith.

Since splenectomy, blood transfusion has been found to be required less frequently. She received three transfusions during the 1st post-operative year, only one transfusion during the 2 nd postoperative year and none during the past 11 months. Each transfusion has coincided with some form of intercurrent infection. Although her haemoglobin averages $7.5 \mathrm{~g} / 100 \mathrm{ml}$, her general health has gradually improved; there is no jaundice and she is now free of symptoms. Her height and weight have remained well below the normal range for a girl of her age but rate of growth has improved during the past year.

\section{Family history}

Both parents are well and have normal levels of haemoglobin and normal red blood cell appearances. Neither gives a history of anaemia or jaundice. Examination of a male sibling, aged 12 months and of the maternal and paternal grandparents has also shown no haematological abnormality.

\section{Discussion}

The clinical and laboratory features of this second case of Haemoglobin Hammersmith are strikingly similar to that reported by Grimes et al. (1964) but both differ from patients with Heinz-body haemolytic anaemia due to other forms of unstable haemoglobin. Both cases with Haemoglobin Hammersmith were females and recognized during early childhood, intermittent jaundice being noticed from birth. In neither case were the Heinz bodies seen until a splenectomy had been performed probably because they had been removed by the spleen without destroying the red cells. Fine intracytoplasmic granules in the cells lining the splenic sinusoids from a patient with Haemoglobin Köln have been demonstrated by Jackson, Way \& Woodliff (1967). The red cell inclusions in patients with an unstable haemoglobin are more coarse in appearance than those seen in red cells following splenectomy for other reasons or where they are induced by drugs or chemicals (Fig. $3)$. This difference might be due to variation in the chemical composition of the precipitated globin. The demonstration of an abnormal haemoglobin in these two cases of Haemoglobin Hammersmith depended finally upon finger printing and peptide analysis but a strong suspicion that a form of haemoglobinopathy was the cause of the Heinz-body haemolytic anaemia was based on simple routine laboratory tests. In neither case was an abnormal haemoglobin shown by electrophoresis on paper or

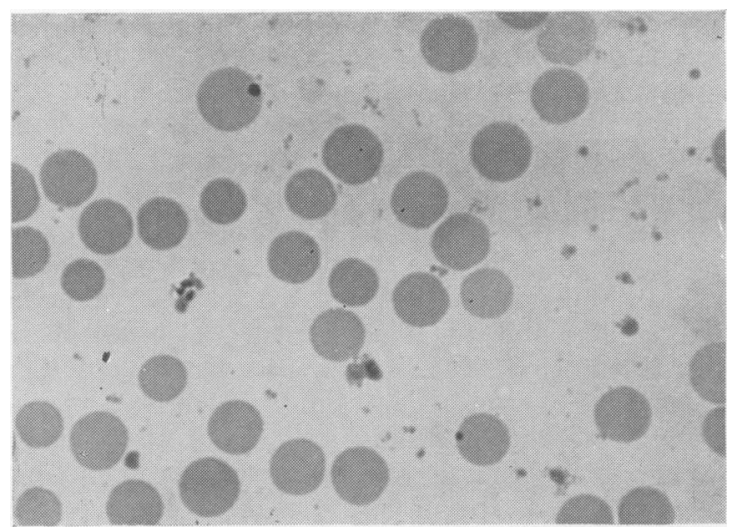

FIG. 3. Photomicrograph of Brilliant cresyl blue stained blood film following splenectomy from a patient with hereditary spherocytosis. There are numerous discrete inclusion bodies in the red cells. $\times 960$.

starch gel but both showed a raised level of haemoglobin F. Methaemoglobinaemia has sometimes helped in the recognition of an unstable haemoglobin but was not found in the present case. The patient of Grimes et al. (1964) excreted dark urine, the cause not being identified but was probably haemoglobin breakdown products such as dipyrrhole compounds (Kreimer-Birnhaum et al., 1966). The most reliable simple method suggesting the presence of an unstable haemoglobin appears to be the occurrence of a precipitate after heating at $50^{\circ} \mathrm{C}$ a stroma-free and Heinz-body free haemolysate.

The only therapeutic measure for controlling the anaemia in either case was blood transfusion but in both the frequency was decreased following splenectomy. This has also been observed in occasional cases with Haemoglobin Köln (Hutchison et al., 1964; Jackson et al., 1967).

All cases reported with unstable haemoglobin haemolytic disease show the abnormality in the heterozygous state but unlike Haemoglobin Zurich and Haemoglobin Köln, family studies in both cases of Haemoglobin Hammersmith failed to show any haematological disturbance or the presence of an abnormal haemoglobin. This raises the possibility that the abnormality has arisen as a mutation in utero.

Heinz bodies have been shown to be denatured globin-products precipitated into the red cell stroma following irreversible changes in the haemoglobin molecule (Jandl, Engle \& Allen, 1960). Where 
instability of haemoglobin has been associated with a change in amino acid sequence this has been found in the $\beta$-chain near the site of haem attachment. In Haemoglobin Zurich: $\beta 63$ histidine $\rightarrow$ arginine (Muller \& Kingma, 1961) the abnormality occurs in the histydyl residue directly opposite the haem group and linked to it via an oxygen molecule in oxyhaemoglobin and via a water molecule in reduced haemoglobin. In Haemoglobin Seattle, the amino acid substitution occurs in tryptic peptide $\beta T-9$, an alanyl being replaced by a glutamyl residue at either position 70 or 76. In Haemoglobin Ube-I the reactive cysteine at position 93 is blocked, and this abnormality is also close to the haem group attachment. The change in Haemoglobin Köln is $\beta 98$ valine $\rightarrow$ methionine and this is adjacent to the haem plate; in Haemoglobin Hammersmith phenylalanine is replaced by serine at position 42 which is in planar relation to the porphyrin ring of the haem plate. While this explanation for an unstable haemoglobin molecule has strong support there remains the possibility that haemolysis could be caused by an interaction of the abnormal haemoglobin with an enzymic defect in the red cell metabolism.

\section{Acknowledgments}

We wish to thank Professor H. Lehmann for help in the preparation of this paper, the staff of the M.R.C Abnormal Haemoglobin Research Unit, Department of Biochemistry, University of Cambridge for the detailed haemoglobin analysis, and Dr A. J. McCall for details of the splenic histology.

\section{References}

Carrell, R.W., Lehmann, H. \& Hutchison, H.E. (1966) Haemoglobin Köln ( $\beta-98$ Valine $\rightarrow$ methionine): an unstable protein causing inclusion-body anaemia. Nature (Lond.), 210, 915.

CATHIE, I.A.B. (1952) Apparent idiopathic Heinz-body anaemia. Gt Ormond Str. J. 3, 43.

DACIE, J.V. (1967) The Haemolytic Anaemias, Part 4. Churchill, London.

Dacie, J.V., Grimes, A.J., Meisler, A., Steingold, L., Hemsted, E.H., Beaven, G.H. \& White, J.C. (1964) Hereditary Heinz-body anaemia. A report of studies on five patients with mild anaemia. Brit. J. Haemat. 10, 388.

Dacie, J.V., Shinton, N.K., GaffNey, P.J., JR, Carrell, R.W. \& LeHMANN, H. (1967) Haemoglobin Hammersmith $(\beta 42(\mathrm{CDi})$ PHE $\rightarrow$ SER). Nature (Lond.), 216, 663.

Frick, P.G., HitzIG, W.H. \& BETKE, K. (1962) Haemoglobin Zurich. Blood, 20, 261.

Grimes, A.J., Meisler, A. \& Dacie, J.V. (1964) Congenital Heinz-body anaemia. Further evidence on the cause of
Heinz-body production in red cells. Brit. J. Haemat. 16, 281.

HeINZ, R. (1890a) Die praktische vermendbarkeit von Phenylhydrazinderivaten als Fiebermittel. Berl. Klin. Woch. 27, 47.

Heinz, R. (1890b). Morphologische Veränderungen der rothen Blutkorperchen durch Grifte. Virchows Arch. 122, 112.

HuEHNS, E.R. (1965) Abnormal haemoglobins causing haemolytic anaemia. Proc. roy. Soc. Med. 58, 514.

Hutchison, H.E., Pinkerton, P.H., Waters, P., Douglas, A.S., LehmanN, H. \& Beale, D. (1964) Hereditary Heinzbody anaemia, thrombocytopenia and haemoglobinopathy (Hb Köln) in a Glasgow family. Brit. med. J. 2, 1099.

JACKSON, J.M., WAY, B.J. \& WoOdLIFF, H.J. (1967) A West Australian family with a haemolytic disorder associated with haemoglobin Köln. Brit. J. Haemat. 13, 474.

JANDL, J.H., ENGLE, L.K. \& AlleN, D.W. (1960) Oxidative haemolysis and precipitation of haemoglobin. I. Heinzbody anaemia as an acceleration of red-cell ageing. J. clin. Invest. 39, 1818.

Kreimer-Birnhaum, M., Pinkerton, P.H., Bannerman, R.M. \& Hutchison, H.E. (1966) Dipyrrolic urinary pigments in congenital Heinz-body anaemia due to $\mathrm{Hb} \mathrm{Köln}$ in thalassaemia. Brit. med. J. 2, 396.

LANGE, R.D. \& ACKeroyd, J.H. (1958) Congenital haemolytic anaemia with abnormal pigment metabolism and red cell inclusion bodies. A new clinical syndrome. Blood, 13, 950.

Muller, C.J. \& Kingma, S. (1961) Haemoglobin Zurich $\alpha_{2} \mathrm{~A}_{\beta_{2}}{ }^{63}$ Arg. Biochim. biophys. Acta (Amst.), 50, 595.

Pribilla, W. (1962) Thalassämie-ahnliche Erkrankung nut neuem Minor-Hämoglobin ( $\mathrm{Hb} \mathrm{Köln}$ ). HaemoglobinColloquium, 31 August 1961 (Ed. by H. Lehmann and K. Betke), p. 73. Stuttgart.

Pribilla, W., Klesse, P., Betke, K., Lehmann, H. \& BEALE, D. (1965) Hämoglobin-Köln-Krankheut: Familiäre hypochromie hämolytische Anämic mit Hämoglobino-? malie. Klin. Wschr. 43, 1049.

ReIss, L. (1882) Aus der inneren Abtheilung des Städtischen Allgemeinen Krankenhauses in Berlin. Ueber Vergiftung mit chlorsaurem Kalium. Berl. Klin. Woch. 19, 785.

Sansone, G. \& Pic, C. (1965) Familial haemolytic anaemia with erythrocyte inclusion bodies, bilifuscinuria and abnormal haemoglobin. Brit. J. Haemat. 11, 511.

Schmid, R., Brecher, G. \& Clemens, T. (1959) Familial hemolytic anemia with erythrocyte inclusion bodies and a defect in pigment metabolism. Blood, 14, 991.

Scott, N.L., Haut, A., Cartwright, G.E. \& Wintrobe, M.M. (1960) Congenital hemolytic disease associated with red cell inclusion bodies, abnormal pigment metabolism and an electrophoretic haemoglobin abnormality. Blood, 16, 1239.

Shibata, S., Iuchi, I., Miyaji, T., Ueda, S. \& Takeda, I. (1963) Haemolytic disease associated with the production of abnormal haemoglobin and intra-erythrocytic Heinz bodies. Acta haemat. jap. 26, 164.

WeBSTER, S.H. (1949) Heinz body phenomenon in erythrocytes. Blood, 4, 479.

Zinkham, W.H. \& LenhaRd, R.E. (1959) Metabolic abnormalities of erythrocytes from patients with congenital nonspherocytic haemolytic anaemia. J. Pediat. 55, 319. 